\title{
PELATIHAN KERJA, MOTIVASI DAN PENGEMBANGAN KARIR PENGARUHNYA TERHADAP KINERJA KARYAWAN PADA PT. RIFAN FINANCINDO BERJANGKA SOLO
}

\author{
Siti Mufidah ${ }^{1}$, Bambang Mursito $^{2}$, Eny Kustiyah $^{3}$ \\ Fakultas Ekonomi Manajemen Universitas Islam Batik Surakarta ${ }^{12) 3)}$ \\ E-mail : sitimufidah3@gmail.com
}

\begin{abstract}
The purpose of this study was to determine the effect of job training, motivation and career development on employee performance The population in this study was PT Rifan Financindo Berjangka Solo. The sample in this study were 50 respondents. The results of testing hypothesis 1 which states the effect of job training on employee performance shows that job training has an effect on employee performance. Hypothesis 2 test results explain that motivation influences employee performance. The results of hypothesis 3 conclude that career development influences employee performance. Simultaneous testing results explain that job training, motivation and career development together affect employee performance.
\end{abstract}

Keywords: job training, motivation, career development.

\section{PENDAHULUAN}

Setiap perusahaan berusaha untuk memiliki sumber daya manusia yang profesional dan terampil dalam menghadapi ketatnya persaingan antara perusahaan yang satu dengan perusahaan yang lain. Dalam hal tersebut Kinerja Karyawan Perlu diperhatikan dengan baik untuk kemajuan perusahaan. Kinerja merupakan hasil kerja secara kualitas dan kuantitas yang dapat dicapai oleh seorang karyawan dalam melaksanakan tugas sesuai dengan tanggung jawab yang diberikan kepadanya (Syitah dan Nasir, 2019).

Perusahaan membutuhkan daya dukung dalam bentuk empat pilar utama untuk mencapai tujuan jangka panjang, ada sumber daya manusia yang berkualitas, sistem yang terintegrasi dan teknologi, strategi yang tepat dan logistik yang memadai. Dalam konteks manajemen operasional, peran sumber daya manusia memiliki posisi sentral. Oleh karena itu, penting untuk memiliki sumber daya berkualitas dengan manusia dalam perusahaan (Reza, Rofiaty dan Djazuli, 2018)

Perkembangan dan pertumbuhan organisasi mempersyaratkan ketersediaan sumber daya manusia yang handal. Upaya menyediakan sumber daya tersebut dapat diperoleh melalui peningkatan kualitas sumber daya manusia. Sumber daya manusia yang berkualifikasi menurut kebutuhan organisasi dapat diperoleh melalui program pelatihan, motivasi dan pengembangan karir yang mendorong tercapainya kinerja pegawai yang terbaik sehingga dapat memberikan penigkatan produktivitas pada organisasi (Massie, Tewal dan Sendow, 2015).

Pelatihan merupakan kewajiban perusahaan dan semua pihak yang terkait dalam pengembangan dan perencanaan usaha. Hal ini dikarenakan dengan diadakannya pelatihan, maka perusahaan melakukan investasi jangka panjang terhadap pengembangan nilai yang dimiliki perusahaan. Pelatihan merupakan suatu cara yang tepat diberikan bagi karyawan dalam meningkatkan mutu kualitas sumber daya manusia di dalam perusahaan (Elisabet Siahaan, 2015). 
Motivasi mempengaruhi seseorang atau individu untuk terlibat dalam kegiatan dan pekerjaan yang mengarah pada tujuan sebagai kepuasan. Karyawan memiliki keinginan kuat yang timbul dari dorongan internal untuk terlibat dan berpartisipasi dalam organisasi dengan melakukan semua tugas dan pekerjaan yang dibebankan dan terus menerus karyawan akan terus mengabdikan diri melalui semua tugas dan kerja sukarela karena kenyamanan dan kesenangan yang didasarkan pada motivasi (Shella, 2018).

Pengembangan karir sebagai kegiatan manajemen SDM pada dasarnya memiliki tujuan untuk dapat memperbaiki dan meningkatkan efektivitas pelaksanaan pekerjaan oleh para pekerja agar semakin mampu memberikan kontribusi terbaik dalam mewujudkan tujuan bisnis organisasi. Individu yang merencanakan dan organisasi yang mengarahkan. Pengembangan karir pegawai adalah pendekatan atau kegiatan yang tersusun secara formal untuk meningkatkan pertumbuhan, kepuasan kerja, pengetahuan, dan kemampuan pegawai agar organisasi dapat memastikan bahwa orang-orang dengan kualifikasi dan pengalaman yang cocok tersedia dalam organisasi. Nami Nasution, Mariatin dan Zahreni (2018) menunjukkan bahwa pengembangan karir adalah proses dalam suatu organisasi untuk meningkatkan kemampuan individu untuk mencapai karir yang diharapkan.

Pelatihan, pengembangan dan motivasi adalah hal yang sangat mempengaruhi kinerja karyawan dan berpengaruh terhadap produktivitas sebuah perusahaan. Seperti pada perusahaan finance, yang dituntut untuk terus melakukan pembenahan di berbagai aspek. Objek yang digunakan untuk penelitian ini yaitu PT. Rifan Financindo Berjangka Solo, merupakan salah satu perusahaan yang bergerak di bidang perdagangan berjangka komoditi yang memiliki reputasi bisnis yang baik dan konsisten dalam misi pengembangan iklim investasi di Indonesia. PT. Rifan financindo berjangka adalah anggota dari dua bursa berjangka yaitu Bursa Berjangka Jakarta (BBJ) dan Indonesia Commodity and Derivative Exchange (ICDX). Perusahaan berkomitmen untuk melaksanakan perdagangan berjangka untuk memberikan kepastian hukum bagi semua pihak dalam kegiatan perdagangan berjangka di Indonesia.

\section{TINJAUAN PUSTAKA}

\section{Kinerja karyawan}

Setiap karyawan dituntut untuk memberikan kontribusi positif melalui kinerja yang baik,, mengingat kinerja organisasi tergantung pada kinerja karyawannya. Kinerja suatu pegawai tidak lepas dari hasil yang dicapai serta efektif dalam meningkatkan produktivitas, hal tersebut akan sangat menentukan keunggulan daya saing perusahaan, oleh karena itu menurut Tampi, (2014) mendefinisikan kinerja yaitu suatu hasil yang dicapai oleh karyawan dalam pekerjaanya menurut kriteria tertentu yang berlaku untuk suatu pekerjaan. Kinerja merupakan suatu kondisi yang harus diketahui dan dikonfirmasikan kepada pihak tertentu untuk mengetahui tingkat pencapaian hasil individu dihubungkan dengan visi yang diemban suatu organisasi, serta mengetahui dampak positif dan negatif dari suatu kebijakan operasional (Hotiana dan Febriansyah, 2018).

Pada suatu perusahaan, kinerja atau performance merupakan gambaran mengenai tingkat pencapaian pelaksanaan suatu program kegiatan atau kebijakan dalam mewujudkan sasaran, tujuan, visi dan misi organisasi yang dituangkan melalui perencanaan strategis suatu organisasi. Banyak faktor yang mempengaruhi kinerja karyawan, seperti kedisiplinan, lingkungan kerja, kepemimpinan, perekrutan, seleksi dan lain sebagainya, dalam penelitian ini dilihat daripada kajian penelitian yg relevan dan hasil peniliitian pendahulu yg telah dilakukan, kinerja karyawan dipengaruhi oleh pelatihan kerja, motivasi dan pengembangan karir. 


\section{Pelatihan Kerja}

Teknologi berkembang sangat pesat dan organisasi yang tidak mampu merespons dengan baik kemajuan teknologi akan kalah dalam persaingan bisnisnya. Salah satu cara yang harus dilakukan adalah melatih karyawan agar memiliki keterampilan terhadap teknologi yang berkembang tersebut. Pelatihan yang dilakukan dengan baik dan tepat akan memungkinkan kinerja karyawan menjadi baik. Pemberian pelatihan sangat penting bagi karyawan, karena dapat meningkatkan pengetahuan bagi karyawan terhadap pekerjaan.

Pemberian pelatihan dapat meningkatkan prestasi kerja dan motivasi karyawan. Pelatihan menurut (Massie, Tewal and Sendow, 2015) adalah proses meningkatkan pengetahuan dan ketramplian karyawan. Pelatihan meliputi pengubahan sikap sehingga karyawan dapat melakukan pekerjaannya lebih efekti serta upaya yang berkaitan dengan peningkatan kemampuan atau keterampilan karyawan yang sudah menduduki suatu pekerjaan atau tugas tertentu

Pelatihan itu sendiri merupakan suatu cara yang tepat diberikan bagi karyawan dalam meningkatkan mutu kualitas sumber daya manusia di dalam perusahaan. Pelatihan akan mendukung kinerja karyawan dan motivasi kerja. Pelatihan ini berguna untuk meningkatkan The hard skill dari Millenial Auditor tidak diremehkan oleh senior atau atasan dan soft skill dari Millenial Auditor memiliki etika yang baik dalam bekerja untuk mengurangi gesekan dalam pekerjaan (Reza, Rofiaty and Djazuli, 2018).

\section{Motivasi}

Setiap karyawan memiliki tujuan tertentu dalam bekerja. Semakin kuat tujuan yang mendasarinya, maka akan semakin besar motivasi seseorang untuk mencapainya. Motivasi yang dimiliki seseorang akan menentukan kinerjanya dalam bekerja. Kekuatan potensial yang ada di dalam diri seorang manusia, yang dapat dikembangkannya sendiri atau dikembangkan oleh sejumlah kekuatan luar yang pada intinya berkisar sekitar imbalan moneter dan imbalan non moneter, yang dapat mempengaruhi hasil kinerjanya secara positif atau negatif.

Motivasi itu sendiri Menurut Ridwansyah, Sadalia Isfenti, Absah Yeni (2018), merupakan sebuah dorongan yang menyebabkan seorang anggota organisasi bersedia untuk menggunakan kemampuannya (dalam bentuk keahlian atau keterampilan), energi, dan waktu untuk melaksanakan beberapa kegiatan dalam tanggung jawabnya, serta nya tugas yang telah ditentukan sebelumnya. Hal ini sesuai dengan (Manggis, Yuesti dan Sapta, 2018) bahwa motivasi kerja merupakan suatu dorongan yang membuat seseorang bertindak atau berperilaku dengan cara tertentu dengan kemungkinan pemenuhan tujuan atau kebutuhan dalam pekerjaan pribadi.

Motivasi mempengaruhi seseorang atau individu untuk terlibat dalam kegiatan dan pekerjaan yang mengarah pada tujuan sebagai kepuasan. Karyawan memiliki keinginan kuat yang timbul dari dorongan internal untuk terlibat dan berpartisipasi dalam organisasi dengan melakukan semua tugas dan pekerjaan yang dibebankan dan terus menerus karyawan akan terus mengabdikan diri melalui semua tugas dan kerja sukarela karena kenyamanan dan kesenangan yang didasarkan pada motivasi (Shella, 2018).

\section{Pengembangan Karir}

Setiap karyawan menginginkan adanya pengembangan karir dalam organisasi tempat kerjanya. Karir seseorang akan berkembang baik dalam organisasi jika ia mampu menunjukkan kinerja yang tinggi. Dengan adanya perencanaan karier yang baik dalam rangka mengembangkan karier diri, maka seseorang akan dapat membuat taktik, apa yang harus dilakukan untuk meraih jenjang tertentu. Pengembangan karir mempunyai berbagai manfaat 
karir jangka panjang yang membantu pegawai untuk tanggung jawab lebih besar di waktu yang akan datang

Pengembangan karir itu sendiri secara umum dapat diartikan sebagai upaya perubahan atau peningkatan karier pegawai dari suatu jabatan lain dalam ruang dan golongan yang berbeda. Wirotomo dan Pasaribu (2007) Pengembangan karir adalah suatu kondisi yang menunjukkan adanya peningkatan peningkatan status seseorang dalam suatu organisasi dalam jalur karir yang telah ditetapkan dalam organisasi yang bersangkutan.

Dalam suatu perusahaan pengembangan karir merupakan peningkatan pribadi yang dilakukan seseorang untuk mencapai suatu rencana karir dan peningkatan oleh departemen personalia untuk mencapai suatu rencana kerja sesuai dengan jalur atau jenjang organisasi. Salah satu dimensi yang mempengaruhi kepuasan kerja seseorang adalah adanya kesempatan mengembangkan karirnya dalam bentuk peluang promosi.

\section{Hipotesis}

\section{Pengaruh pelatihan kerja, motivasi dan pengembangan karir terhadap kinerja karyawan}

Penelitian yang dilakukan (Elisabet Siahaan, 2015) menunjukan bahwa secara simultan variabel Pelatihan dan motivasi berpengaruh terhadap kinerja karywan PT. Perkebunan Nusantara III. Penelitian yang dilakukan motivasi (Harlie, 2010) menunjukan bahwa secara simultan motivasi dan pengembangan karir berpengaruh terhadap kinerja karyawan di Pemerintah Kabupaten Tabalong. Penelitian yang dilakukan (Syitah dan Nasir, 2019) menunjukan bahwa secara simultan pelatihan dan pengembangan karir berpengaruh terhadap kinerja karyawan PT. Pegadaian Keutapang. Berdasarkan uraian tersebut maka hipotesis pertama dalam penelitian ini:

$\mathrm{H}_{1}$ : Diduga pelatihan kerja, motivasi dan pengembangan karir berpengaruh positif dan signifikan terhadap kinerja karyawan PT. Rifan Financindo Berjangka.

\section{Pengaruh pelatihan kerja terhadap kinerja karyawan}

Penelitian yang dilakukan (Massie, Tewal and Sendow, 2015) menunjukan bahwa pelatihan berpengaruh signifikan terhadap kinerja karyawan pada Museum Negeri Sulawesi Utara. Penelitian yang dilakukan (Reza, Rofiaty and Djazuli, 2018) menunjukan bahwa terdapat pengaruh signifikan pelatihan terhadap kinerja karyawan pada PT. Bank BRI Malang. Penelitian yang dilakukan (Thaief et al., 2015) menunjukan bahwa pelatihan berpengaruh signifikan terhadap kinerja karyawan. Berdasarkan uraian tersebut maka hipotesis kedua dalam penelitian ini:

$\mathrm{H}_{2}$ : Diduga Pelatihan Kerja berpengaruh positif dan signifikan terhadap kinerja karyawan PT. Rifan Financindo Berjangka.

\section{Pengaruh motivasi terhadap kinerja karyawan}

Penelitian yang dilakukan Tampi (2014) menunjukan bahwa motivasi berpengaruh terhadap kinerja karyawan PT. Bank BNI Manado. Penelitian yang dilakukan Nila Hotiana dan Febriansyah (2018) menunjukan bahwa motivasi berpengaruh positif dan signifikan terhadap kinerja karyawan. Penelitian yang dilakukan Ridwansyah Sadalia Isfenti, Absah Yeni (2018) menunjukan bahwa motivasi berpengaruh positif dan signifikan terhadap kinerja karyawan. Berdasarkan uraian tersebut maka hipotesis ketiga dalam penelitian ini:

$\mathrm{H}_{3}$ : Diduga motivasi berpengaruh positif dan signifikan terhadap kinerja karyawan di PT.Rifan Financindo Berjangka. 


\section{Pengaruh pengembangan karir terhadap kinerja karyawan}

Penelitian yang dilakukan (Nami Nasution, Mariatin and Zahreni, 2018) menunjukan bahwa pengembangan karir berpengaruh signifikan terhadap kinerja karyawan. Penelitian yang dilakukan (Manggis, Yuesti and Sapta, 2018) menunjukan bahwa pengembangan karir berpengaruh signifikan terhadap kinerja karyawan. Penelitian yang dilakukan (Charity, 2015) menunjukan bahwa pengembangan karir berpengaruh signifikan terhadap kinerja karyawan. Berdasarkan uraian tersebut maka hipotesis keempat dalam penelitian ini:

$\mathrm{H}_{4}$ : Diduga pengembangan karir berpengaruh positif dan signifikan terhadap kinerja karyawan di PT. Rifan Financindo Berjangka Solo.

\section{METODOLOGI PENELITIAN}

Pendekatan yang dilakukan dalam penelitian ini adalah pendekatan analisis kuantitatif berdasarkan informasi statistika. Pendekatan penelitian yang dalam menjawab permasalahan penelitian memerlukan pengukuran yang cermat terhadap variabel-variabel dari objek yang diteliti untuk menghasilkan kesimpulan yang dapat digeneralisasikan terlepas dari konteks waktu, tempat dan situasi. Metode kuantitatif juga dapat diartikan sebagai metode penelitian yang berlandaskan pada filsafat positivisme.

Penelitian ini dilakukan di PT. Rifan Financindo Berjangka Solo, yang beralamat di jalan Slamet Riyadi Ruko Mall Solo Square No 5-7 Laweyan Surakarta. Pengambilan data penelitian mulai dilakukan pada bulan Oktober sampai dengan bulan Desember tahun 2019.

Pada penelitian ini yang dijadikan sample yaitu sebanyak 50 responden, dari 120 populasi. Teknik pengambilan sampel menggunakan probably sampling dengan simple random sampling yaitu pengambilan sampel secara acak dari populasi karena populasi dianggap homogen.

Teknik Probably sampling dengan simple random sampling yaitu cara pengambilan sampel dengan memilih langsung dari populasi dan besar peluang setiap anggota populasi untuk menjadi sampel, kemudian diolah dengan menggunakan teknik analisis dengan uji asumsi klasik, regresi linier berganda, $\mathrm{R}^{2,}$ uji F serta uji t.

\section{HASIL DAN PEMBAHASAN}

\section{1) Variabel Penelitian}

\section{Variabel Dependen}

Variabel terikat (dependen) adalah variabel yang dipengaruhi oleh variable bebas (independen). Variabel ini disebut juga variabel akhir atau variabel endogen atau variable akibat (Ghozali, 2011:95). Variabel terikat yang digunakan dalam penelitian ini adalah Kinerja Karyawan (Y).

\section{Variabel Independen}

Variabel bebas (independen) adalah variabel yang mempengaruhi variabel terikat (dependen), baik pengaruh positif maupun negatif. Variabel ini disebut juga variabel awal atau variabel eksogen atau variabel penyebab. Variabel independen yang digunakan dalam penelitian ini adalah Pelatihan Kerja (X1), Motivasi (X2) dan Pengembangan Karir (X3).

\section{2) Analisis Data}

\section{Uji Koefisien Determinasi}

Berikut hasil uji Koefisien Determinasi 


\begin{tabular}{lll}
\hline Adjusted R Square & Keterangan \\
\hline 0,738 & Berpengaruh $73,8 \%, \quad 26,2 \%$ \\
& pengaruh variabel lain \\
\hline
\end{tabular}

Hasil uji koefisien determinasi diatas menunjukan hasil perhitunga $\mathrm{R}^{2}$ diperoleh dalam analisis regresi berganda dan diperoleh angka koefisien determinasi dengan nilai Adjustes $R$ Square sebesar 0,738. Hal ini menunjukan bahwa variansi pada variabel praktek kinerja karyawan sebesar $73,8 \%$ dapat dijelaskan oleh variabel pelatihan kerja, motivasi dan pengembangan karir sedangkan sisanya $26,2 \%$ dijelaskan oleh faktor - faktor lain diluar yang diteliti.

\section{Uji Regresi}

Berikut hasil uji Regresi Linear Berganda

\begin{tabular}{lll}
\hline \multicolumn{1}{c}{ Variabel } & B \\
\hline Constant & $-6,022$ & \\
Pelatihan Kerja & 0,290 & \\
Motivasi & 0,705 & \\
Pengembangan Karir & 0,306 & \\
\hline
\end{tabular}

$$
\mathrm{Y}=-\mathbf{6 , 0 2 2}+\mathbf{0 , 2 9 0}(\mathrm{X} 1)+0,705(\mathrm{X} 2)+0,306(\mathrm{X} 3)
$$

\section{Uji Asumsi Klasik}

\section{a. Uji Normalitas}

Berikut hasil uji Normalitas

\begin{tabular}{lll}
\hline Kolmogorov Smirnov & \multicolumn{1}{c}{ Signifikansi } & \multicolumn{2}{c}{ Keterangan } \\
\hline 0,200 & $>0,05$ & $\begin{array}{l}\text { Data } \\
\text { normal }\end{array}$ \\
\hline
\end{tabular}

Uji normalitas dalam penelitian ini menunjukkan nilai signifikansi sebesar 0,200 >0,05, maka penelitian ini dapat disimpulkan data berdistribusi normal.

\section{b. Uji Multikolinearitas}

Berikut hasil uji Multikolinearitas

\begin{tabular}{|c|c|c|c|c|c|}
\hline Variabel & Tolerance & Sig & VIF & Sig & Keterangan \\
\hline $\begin{array}{l}\text { Pelatihan } \\
\text { Kerja }\end{array}$ & 0,550 & $>0,1$ & 1,817 & $<10$ & $\begin{array}{l}\text { Tidak terjadi } \\
\text { multikolienaritas }\end{array}$ \\
\hline Motivasi & 0,718 & $>0,1$ & 1,393 & $<10$ & $\begin{array}{l}\text { Tidak terjadi } \\
\text { multikolienaritas }\end{array}$ \\
\hline $\begin{array}{l}\text { Pengembangan } \\
\text { Karir }\end{array}$ & 0,589 & $>0,1$ & 1,697 & $<10$ & $\begin{array}{l}\text { Tidak terjadi } \\
\text { multikolienaritas }\end{array}$ \\
\hline
\end{tabular}

Hasil uji multikolinearitas dalam penelitian menunjukkan nilai tolerance $>0,1$ dan nilai VIF < 10, sehingga dapat disimpulkan bahwa penelitian ini tidak terjadi multikolinearitas. 


\section{c. Uji Heteroskesdastisitas}

Berikut hasil uji Heteroskedastisitas

\begin{tabular}{llll}
\hline Variabel & P Value & Sig & Keterangan \\
\hline Pelatihan Kerja & 0,977 & $>0,05$ & $\begin{array}{l}\text { Bebas } \\
\text { heteroskesdastisitas } \\
\text { Motivasi }\end{array}$ \\
$\begin{array}{lll}\text { Bebas } \\
\text { heteroskesdastisitas }\end{array}$ \\
$\begin{array}{l}\text { Pengembangan } \\
\text { Karir }\end{array}$ & 0,894 & $>0,05$ & $\begin{array}{l}\text { Bebas } \\
\text { heteroskesdastisitas }\end{array}$ \\
\hline
\end{tabular}

Hasil uji heteroskesdastisitas menunjukkan nilai $P$ Value lebih besar dari signifikansi 0,05 , artinya variabel pendidikan dan pelatihan pengguna SIA bebas heteroskesdastisitas.

\section{d. Uji Autokorelasi}

Hasil Uji Autokorelasi

\begin{tabular}{llll}
\hline Du & DW & 4-Du & Keterangan \\
\hline 1,673 & 1,895 & 2,327 & $\begin{array}{l}\text { Tidak terjadi } \\
\text { autokorelasi }\end{array}$ \\
\hline
\end{tabular}

Hasil penelitian uji autokorelasi didapat nilai Du $(1,673)<\mathrm{DW}(1,895)<4-\mathrm{Du}(2,327)$, sehingga dapat disimpulkan bahwa penelitian tidak terjadi autokorelasi.

\section{Uji Kelayakan Model}

Uji kelayakan model digunakan untuk melihat bagaimanakah pengaruh semua variabel bebasnya secara bersama - sama terhadap variabel terikatnya. Berikut hasil uji kelayakan model penelitian :

Tabel 5 : Hasil Uji Kelayakan Model

\begin{tabular}{lllll}
\hline F Hitung & F Tabel & Sig & Std & Keterangan \\
\hline 46,932 & $>2,81$ & 0,000 & $<0,05$ & $\begin{array}{l}\text { Model layak } \\
\text { digunakan }\end{array}$ \\
\hline
\end{tabular}

Uji kelayakan model diatas hasil nilai $F$ hitung $>\mathrm{F}$ tabel $(46,932>2,81)$ dan signifikansi $(0,000)<0,05$, maka H0 ditolak (Ha diterima). Dengan demikian secara simultan variabel independen (pelatihan kerja, motivasi dan pengembangan karir) berpengaruh terhadap variabel dependen (kinerja karyawan). Jadi dapat disimpulkan bahwa model layak digunakan.

\section{Uji t}

Uji t digunakan untuk menguji bagaimana pengaruh masing - masing variabel bebasnya secara sendiri - sendiri terhadap variabel terikatnya :

Tabel 6 : Hasil Uji t Penelitian

\begin{tabular}{llllll}
\hline Hipotesis & t Hitung & t Tabel & Sig & Std & Keterangan \\
\hline H1 & 2,183 & $>2,012$ & 0,034 & $<0,05$ & Diterima \\
H2 & 6,676 & $>2,012$ & 0,000 & $<0,05$ & DIterima \\
H3 & 2,560 & $>2,012$ & 0,014 & $<0,05$ & Diterima \\
\hline
\end{tabular}




\section{Pembahasan}

\section{1) Pengaruh pelatihan kerja terhadap kinerja karyawan}

Hasil pengujian hipotesis 1 menunjukkan bahwa pelatihan kerja berpengaruh terhap kinerja karyawan. Artinya apabila pelatihan kerja dalam perusahaan diterapkan dengan baik, maka akan semakin meningkat kinerja karyawan dalam perusahaan. Pelatihan menghasilkan manfaat bagi karyawan dengan positif mempengaruhi kinerja karyawan melalui pengembangan pengetahuan, keterampilan, kemampuan, kompetensi dan perilaku.

Pelatihan kerja yang diterapkan oleh PT. Rifan Financindo Berjangka Solo berjalan baik, sehingga para karyawan semakin meningkat kemampuan yang dimiliki serta keterampilannya. Ini membuat karyawan PT Rifan Financindo Berjangka Solo meningkatkan kinerja karyawan, dengan meningkatnya kinerja karyawan diharapkan dapat meningkatkan pendapatan perusahaan.

Penelitian ini sejalan dengan yang dilakukan (Massie, Tewal and Sendow, 2015) menunjukan bahwa pelatihan berpengaruh signifikan terhadap kinerja karyawan pada Museum Negeri Sulawesi Utara. Penelitian yang dilakukan (Reza, Rofiaty and Djazuli, 2018) menunjukan bahwa terdapat pengaruh signifikan pelatihan terhadap kinerja karyawan pada PT. Bank BRI Malang. Penelitian yang dilakukan (Thaief et al., 2015) menunjukan bahwa pelatihan berpengaruh signifikan terhadap kinerja karyawan.

\section{2) Pengaruh motivasi terhadap kinerja karyawan}

Hasil pengujian hipotesis 2 menjelaskan bahwa motivasi berpengaruh terhadap kinerja karyawan. Pemahaman terhadap motivasi kerja dalam meningkatkan kinerja karyawan mengarahkan pada pengertian betapa pentingnya motivasi kerja sebagai bagian dari upaya perusahaan untuk meningkatkan kesejahteraan karyawan yang berakhir pada peningkatan kinerja. Motivasi sangatlah penting diberikan kepada karyawan untuk menaikan kinerja karyawan. Dengan memberikan motivasi yang tepat diharapkan setiap karyawan akan terdorong untuk meningkatkan kinerjanya.

Motivasi terbentuk dari sikap pegawai dalam menghadapi situasi kerja di perusahaan. Motivasi merupakan kondisi atau energi yang menggerakkan diri pegawai yang terarah untuk mencapai tujuan perusahaan. Sikap mental pegawai yang positif terhadap situasi kerja itulah yang memperkuat motivasi kerjanya untuk dapat mencapai kinerja semaksimal mungkin.

Disamping itu terdapat beberapa aspek yang berpengaruh terhadap motivasi kerja pegawai, yaitu rasa aman dalam bekerja, mendapatkan gaji yang adil dan kompetitif, lingkungan kerja yang menyenangkan, penghargaan atas prestasi kerja dan perlakuan yang adil dari manajemen. Dengan melibatkan pegawai dalam pengambilan keputusan, pekerjaan yang menarik, rekan-rekan kerja yang menyenangkan, kejelasan akan standar keberhasilan, hasil yang diharapkan serta bangga terhadap pekerjaan dan perusahaan, merupakan faktor peningkatan prestasi kerja pegawai.

Dengan demikian jelaslah, bahwa motivasi yang tepat maka para pegawai akan terdorong untuk berbuat semaksimal mungkin untuk melaksanakan pekerjaannya, karena apabila suatu perusahaan berhasil mencapai tujuannya, maka kepentingan para pegawainya pasti akan terjamin. Dari uraian diatas, maka unsur motivasi sangat berpengaruh terhadap prestasi kerja pegawai, sehingga dapat dicapai tujuan pribadi maupun tujuan perusahaan yang telah ditetapkan sebelumnya.

Penelitian ini sejalan dengan yang dilakukan Tampi (2014) menunjukan bahwa motivasi berpengaruh terhadap kinerja karyawan PT. Bank BNI Manado. Penelitian yang dilakukan Nila Hotiana dan Febriansyah (2018) menunjukan bahwa motivasi berpengaruh positif dan 
signifikan terhadap kinerja karyawan. Penelitian yang dilakukan Ridwansyah Sadalia Isfenti, Absah Yeni (2018) menunjukan bahwa motivasi berpengaruh positif dan signifikan terhadap kinerja karyawan.

\section{3) Pengaruh pengembangan karir terhadap kinerja karyawan}

Hasil hipotesis 3 menyimpulkan bahwa pengembangan karir berpengaruh terhadap kinerja karyawan. Hal ini dapat diartikan bahwa dengan adanya perencanaan karir yang baik dalam rangka mengembangkan karir diri, maka seseorang akan dapat membuat taktik, apa yang harus dilakukan untuk meraih jenjang tertentu.

Pengembangan karir mempunyai berbagai manfaat karir jangka panjang yang membantu pegawai untuk tanggung jawab lebih besar di waktuyang akan datang. Pegawai harus dilatih dan dikembangkan di bidang tertentu untuk mengurangi dan menghilangkan kebiasan kerja yang jelek atau untuk mempelajari keterampilan baru yang akan meningkatkan kinerja mereka.

Penelitian yang dilakukan (Nami Nasution, Mariatin and Zahreni, 2018) menunjukan bahwa pengembangan karir berpengaruh signifikan terhadap kinerja karyawan. Penelitian yang dilakukan (Manggis, Yuesti and Sapta, 2018) menunjukan bahwa pengembangan karir berpengaruh signifikan terhadap kinerja karyawan. Penelitian yang dilakukan (Charity, 2015) menunjukan bahwa pengembangan karir berpengaruh signifikan terhadap kinerja karyawan.

\section{KESIMPULAN}

Tujuan penelitian ini adalah untuk mengetahui pengaruh pelatihan kerja, motivasi dan pengembangan karir terhadap kinerja karyawan Populasi dalam penelitian ini adalah PT Rifan Financindo Berjangka Solo. Sampel dalam penelitian ini sebanyak 50 responden.

Hasil pengujian hipotesis 1 yang menyatakan pengaruh pelatihan kerja terhadap kinerja karyawan menunjukkan bahwa pelatihan kerja berpengaruh terhap kinerja karyawan. Artinya apabila pelatihan kerja dalam perusahaan diterapkan dengan baik, maka akan semakin meningkat kinerja karyawan dalam perusahaan. Pelatihan menghasilkan manfaat bagi karyawan dengan positif mempengaruhi kinerja karyawan melalui pengembangan pengetahuan, keterampilan, kemampuan, kompetensi dan perilaku. Hasil pengujian hipotesis 2 menjelaskan bahwa motivasi berpengaruh terhadap kinerja karyawan. Pemahaman terhadap motivasi kerja dalam meningkatkan kinerja karyawan mengarahkan pada pengertian betapa pentingnya motivasi kerja sebagai bagian dari upaya perusahaan untuk meningkatkan kesejahteraan karyawan yang berakhir pada peningkatan kinerja. Dengan memberikan motivasi yang tepat diharapkan setiap karyawan akan terdorong untuk meningkatkan kinerjanya. Hasil hipotesis 3 menyimpulkan bahwa pengembangan karir berpengaruh terhadap kinerja karyawan. Hal ini dapat diartikan bahwa dengan adanya perencanaan karir yang baik dalam rangka mengembangkan karir diri, maka seseorang akan dapat membuat taktik, apa yang harus dilakukan untuk meraih jenjang tertentu.

\section{DAFTAR PUSTAKA}

Charity, B. C. (2015) 'Effect of Training and Career Development on Employee Performance: a Case of Kcb Branches in the North Rift Region, Kenya', International Journal of Advanced Research in Management and Social Sciences, 4(5), pp. 38-49. Available at: www.garph.co.uk. 
Elisabet Siahaan, E. M. S. (2015) 'Pengaruh pelatihan dan motivasi kerja terhadap kinerja karyawan pt perkebunan nusantara iv (persero) medan tesis', Agrica (Jurnal Agribisnis Sumatera Utara), 8(2), pp. 14-26. doi: 10.31289/agrica.v8i2.1077.

Harlie, M. (2010) 'Pengaruh Disiplin Kerja, Motivasi dan Pengembangan Karier Terhadap Kinerja Pegawai Negeri Sipil Pada Pemerintah Kabupaten Tabalong di Tanjung Kalimantan Selatan', Jurnal Manajemen dan Akuntansi, 11, pp. 117-124.

Hotiana, N. and Febriansyah (2018) 'Pengaruh Motivasi Dan Stres Kerja Terhadap Kinerja Pegawai (Studi Pada Bagian Kepegawaian Dan Organisasi, Biro Umum, Kepegawaian Dan Organisasi Kementerian Pariwisata Ri)', Riset Manajemen dan Bisnis Fakultas UNIAT, 3(1), pp. 27-36.

Manggis, I. W., Yuesti, A. and Sapta, I. K. S. (2018) 'The Effect of Career Development and Organizational Culture to Employee Performance with Motivation of Work as Intervening Variable in Cooperation in Denpasar Village', International Journal of Contemporary Research and Review, 9(07), pp. 20901-20916. doi: 10.15520/ijcrr/2018/9/07/553.

Massie, R., Tewal, B. and Sendow, G. (2015) 'Pengaruh Perencanaan Karir, Pelatihan Dan Pengembangan Karir Terhadap Kinerja Pegawai Pada Museum Negeri Provinsi Sulawesi Utara', Jurnal Berkala Ilmiah Efisiensi, 15(05), pp. 635-645.

Nami Nasution, F., Mariatin, E. and Zahreni, S. (2018) 'The Influence of Career Development and Organizational Culture on Employee Performance', International Journal of Scientific Research and Management, 6(01), pp. 57-65. doi: 10.18535/ijsrm/v6i1.el09.

Reza, M., Rofiaty, R. and Djazuli, A. (2018) 'The Influence of Situasional Leadership , Organizational Culture and Training on Employee Performance and Work Motivation of Millenial Generation at the Inspection Office of BRI Malang', Indonesian Journal of Social and Humanity Study, 21(2), pp. 89-95. Available at: http://www.wacana.ub.ac.id/index.php/wacana/article/view/556/400.

Shella, K. (2018) 'RJOAS, 9(81), September 2018', Russian Journal of Agricultural and SocioEconomic Sciences, 9(September), pp. 37-51. doi: https://doi.org/10.18551/rjoas.2018 09.03.

Syitah, S. U. and Nasir (2019) 'Pengaruh Pelatihan Dan Pengembangan Karir Terhadap Kinerja Karyawan Pada Pt Sentosa Plastik Medan', Wahana Inovasi: Jurnal Penelitian dan Pengabdian Masyarakat UISU, 8(1), pp. 446-458.

Tampi, B. J. (2014) 'Pengaruh Gaya Kepemimpinan dan Motivasi Terhadap Kinerja Karyawan Pada PT. Bank Negara Iindonesia, TBK (Regional Sales Manado)', Jurnal 'Acta Diurna' Volume III. No.4., III(4), pp. 1-20.

Wirotomo dan Pasaribu (2015) 'Pengaruh Kompetensi, Pengembangan Karir, Pendidikan dan Pelatihan (Diklat) Terhadap Kinerja Pegawai Direktorat Jenderal Perimbangan Keuangan', Mix, V(3), p. 3. Available at: http://publikasi.mercubuana.ac.id/index.php/Jurnal_Mix/article/view/630/5 